\title{
Profil Beberapa Tanaman Obat di Hutan Sungai Telang Kabupaten Bungo
}

\author{
Akhyarnis Febrialdi \\ Fakultas Pertanian Universitas Muara Bungo \\ febrialdi81@gmail.com
}

\begin{abstract}
Abstrak
Keanekaragaman hutan merupakan potensi besar untuk dimanfaatkan oleh manusia, hutan kabupaten Bungo khusunya Desa sungai telang memiliki potensi keanekaragaman hutan yang dapat dimanfaatkan sebagai tanaman obat. penelitian ini ditujukan untuk mendapatkan Simplisia dan Skrining Fitokimia beberapa Tanaman obat di Hutan Desa sungai Telang Kabupaten Bungo.Tanaman obat yang diskrening dan dibuat simplisianya adalah tanaman disekitar yang tumbuh hutan yang dimanfaatkan oleh masyarakat sekitar hutan tersebut. Dari hasil ekplorasi terdapat 14 Jenis tanaman obat yang sangat sering digunakan oleh masyarakat yaitu Micania Micranta, Morinda citrifoli, Zingiber Casumounar, Physallis peruviann, Isotoma longiflora, M. leucadendra, Averrhoa bilimbi L, Lantana camara Linn, Impatiens balsamina L, Gynura procumbens, Daemonorops didymophyll, Casia Tora L, Jatropha multifida L, dan Oxalis Barrelieri. Dilakukan skrening fitokimia terhadap beberapa tanaman obat tersebut positif mengandung senyawa alkaloid, flavonoid, steroid, saponin dan Fenolik. Dengan terindentifikasinya kimia tanaman tersebut menambah potensi manfaat tanaman tersebut untuk diolah lebih lanjut menjadi obat modern dan pengayaan bahan ajar dan jurnal ilmiah.
\end{abstract}

Kata Kunci: Simplisia, tanaman obat, fitokimia, hutan Desa sungai Telang Kabupaten Bungo

\section{PENDAHULUAN}

Senyawa aktif biologis itu merupakan senyawa metabolit sekunder yang meliputi alkaloid, flavonoid, terpenoid dan steroid. Menurut Kemala et.al (2003) bahwa industri obat tradisional menghasilkan produk yang sebagian besar dalam bentuk jamu dan bahan baku yang digunakan masih bertumpu pada khasiat tumbuhan yang beragam. Pemanfaatan tumbuhan yang memiliki potensi sebagai obat semakin dikembangkan untuk kebutuhan medis baik diproses secara kimiawi maupu tradisional. Adapun jenis simplisia yang digunakan diberbagai merek jamu berupa umbi, akar, rimpang, batang kayu, kulit batang, biji, minyak, talus, kulit buah, bunga, dan terdapat pula yang memanfaatkan semua bagian tumbuhannya

Upaya untuk memberikan nilai tambah dari tanaman yang masih liar yaitu perlu dilakukan penelitian terhadap kandungan kimia serta khasiatnya. Penelitian berupa pengujian fitokimia dan uji aktivitas biologisnya. Salah satu kabupaten di Propinsi Jambi yaitu kabupaten Bungo memiliki luas hutan Dan potensi keanekaragaman hutannya dapat dimanfaatkan untuk kesejahteraan masyarakat dan kebutuhan akan sumber tanaman obat.
Kebiasaan masyarakat sekitar hutan dan ketergantungan masyarakat dengan tanaman hutan khususnya tanaman obat menjadikan suatu 2 awal untuk menganalisa tanaman obat yang sering digunakan oleh masyarakat untuk dikaji komposisi kimianya sebagai awal pemanfaatan dan pengolahan bahan tersebut sebagai obat yang modern.

\section{METODE}

Eksplorasi tanaman obat dilakukan dengan metode survey dan wawancara. Jenisjenis tanaman obat diidentifikasi baik pada tingkat anakan sampai dengan tingkat pohon yang sering dimanfaatkan masyarakat sebagai tanaman obat. Wawancara dilakukan untuk mengetahui jenis-jenis tanaman obat yang sering dimanfaatkan sehari hari. Tanaman obat yang sering digunakan oleh masyarakat tersebut dukumpulkan simplisianya dan dilakukan skrening fitokimia di laboratorium dan didokumentasikan

Untuk tiap tanaman obat yang ditemukan dari hasil eksplorasi dilakukan skrining fitokimia. Uji dilakukan dari simplisia yang dikumpulkan, dapat berupa daun atau batang, atau akar, sesuai dengan bagian bahan yang sering digunakan oleh masyarakat setempat. 


\section{Persiapan Bahan Uji:}

Sampel dicuci dibawah air keran yang mengalir, setelah ditiriskan sebagian bahan uji sampel segar dianalisa secara kualitatif untuk skrining fitokimia dan sebagian dikeringkan dengan oven $60 \mathrm{oc}$, selama 24 jam, kemudian dibuat serbuk (Figen., 2006)

Uji Alkaloid seperti yang dilakukan oleh Santos et al (1989). Uji Flavonoid seperti yang dilakukan oleh (Mi-Jeong A. \& Jim WK., 2005). Uji Steroid seperti yang dilakukan oleh Edeoga HO, Okwu DE. \& Mbaebre BO. 2005. Uji Saponin seperti yang dilakukan menurut Edeoga HO, Okwu DE. \& Mbaebre BO. 2005. Uji Fenolik seperti yang dilakukan oleh Harborne JB. 1973.

Data yang diperoleh dari hasil pengamatan dikelompokkan dengan tabel berdasarkan Nama umumnya, Nama Daerah, Nama Botani, Kegunaan, Bagian yang digunakan serta hasil skrining yang didapatkan

\section{HASIL DAN PEMBAHASAN}

Tanaman obat yang diuji Fitokimia merupakan beberapa tanaman yang sangat sering digunakan oleh masyarakat di sungai telang Kabupaten Bungo. Beberapa masyarakat mengungkapkan bahwa tanaman obat ini digunakan untuk keperluan mengatasi berbagi macam penyakit. Penentuan tanaman yang akan dibuat simplisia dan skrinng fitokimia dengan mewawancarai beberapa masyarakat yang sering menggunakan tanaman obat. Wawancara dilakukan untuk mengetahui jenis-jenis tanaman obat yang sering dimanfaatkan sehari hari dengan memanfaatkan informan atau tokoh kunci seperti orang tua, dukun kampung dan tokoh masyarakat (Febrialdi dan Subagiono, 2014). Tanaman obat yang sering digunakan oleh masyarakat tersebut dukumpulkan simplisianya dan dilakukan skrining fitokimia di laboratorium dan didokumentasikan.

Pengumpulan Informasi melalui wawancara. dengan perangkat desa. Di Kabupaten Bungo, kepala desa dipanggil dengan sebutan Rio. Informasi yang didapat dari sekretaris Rio desa sungai telang, masih banyak masyarakat yang memanfaatkan hasil hutan untuk kebutuhan hidup dan untuk obat obatan sederhana
Dua puluh delapan jenis Tanaman yang dapat dimanfaatkan sebagai obat digunakan oleh masyarakat di sekitar hutan Kecamatan bathin III ulu Kabupaten Bungo (Febrialdi dan Subagiono, 2014). Berdasarkan pengisian kuesioner dari 50 warga yang ditanyakan Tanaman yang paling sering digunakan masyarakat di lokasi penelitian disampaikan pada tabel 1 .

\section{Simplisia Tanaman Obat}

Tanaman obat dibuat simplisia dalam bentuk kering tanaman utuh. Simplisi dapat diartikan sebagai bahan alamiah yang digunakan sebagai obat yang belum mengalami pengolahan apapun atau telah diolah secara sederhana. mengatakan bahwa Simplisia merupakan bahan alami yang digunakan untuk obat dan belum mengalami perubahan proses apa pun dan pada umumnya dalam bentuk kering. Simplisia tanaman dapat berupa akar, batang, daun rimpang, umbi, batang kulit, kayu, daun, buah, kelopak bunga.

Pembuatan simplisia tanaman obat yang didapat dengan pengeringan diangin anginkan tanpa paparan sinar matahari secara langsung. Hal ini bertujuan agar senyawa aktif dalam sampel tidak mengalami kerusakan dan kadar air dalam sampel berkurang. Selain sampel lebih awet, pengurangan kadar air akan memudahkan pelarut menarik komponen bioaktif dalam sampel saat maserasi (Sudirman dkk, 2011).

nformasi dari masyarakati Ciplukan (Physallis peruvianna) atau buah toup merupakan tanaman yang dapat digunakan untuk obat luka, malaria dan panas dalam. Daun Ciplukan (Physalis angulata) bermanfaat sebagai obat penyembuhan patah tulang, busung air, bisul, borok, penguat jantung, keseleo, nyeri perut, dan kencing nanah. Sedangkan buah ciplukan sendiri sering dimakan langsung untuk mengobati epilepsi, sulit buang air kecil, dan penyakit kuning. Tanaman ciplukan (Physallis peruviana L.) dapat meluruhkan batu ginjal (Andrianto.D, N. Anaser, M. Untoro, R.Fatmawati, R.A. Winda, 2012).

Menurut masyarakat di lokasi penelitian ini, Micania micranta atau rumput PKI dapat digunakan untuk penyembuhan luka. Tanaman ini dapat menyembuhkan luka (Utami Sri, 2012) 
Tanaman yang sering digunakan dilakukan uji fitokimia untuk menentukan senyawa aktif dalam tanaman tersebut.

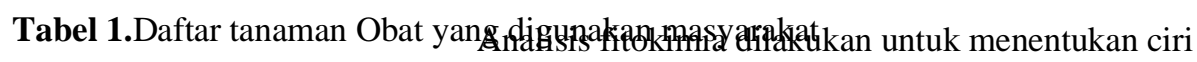

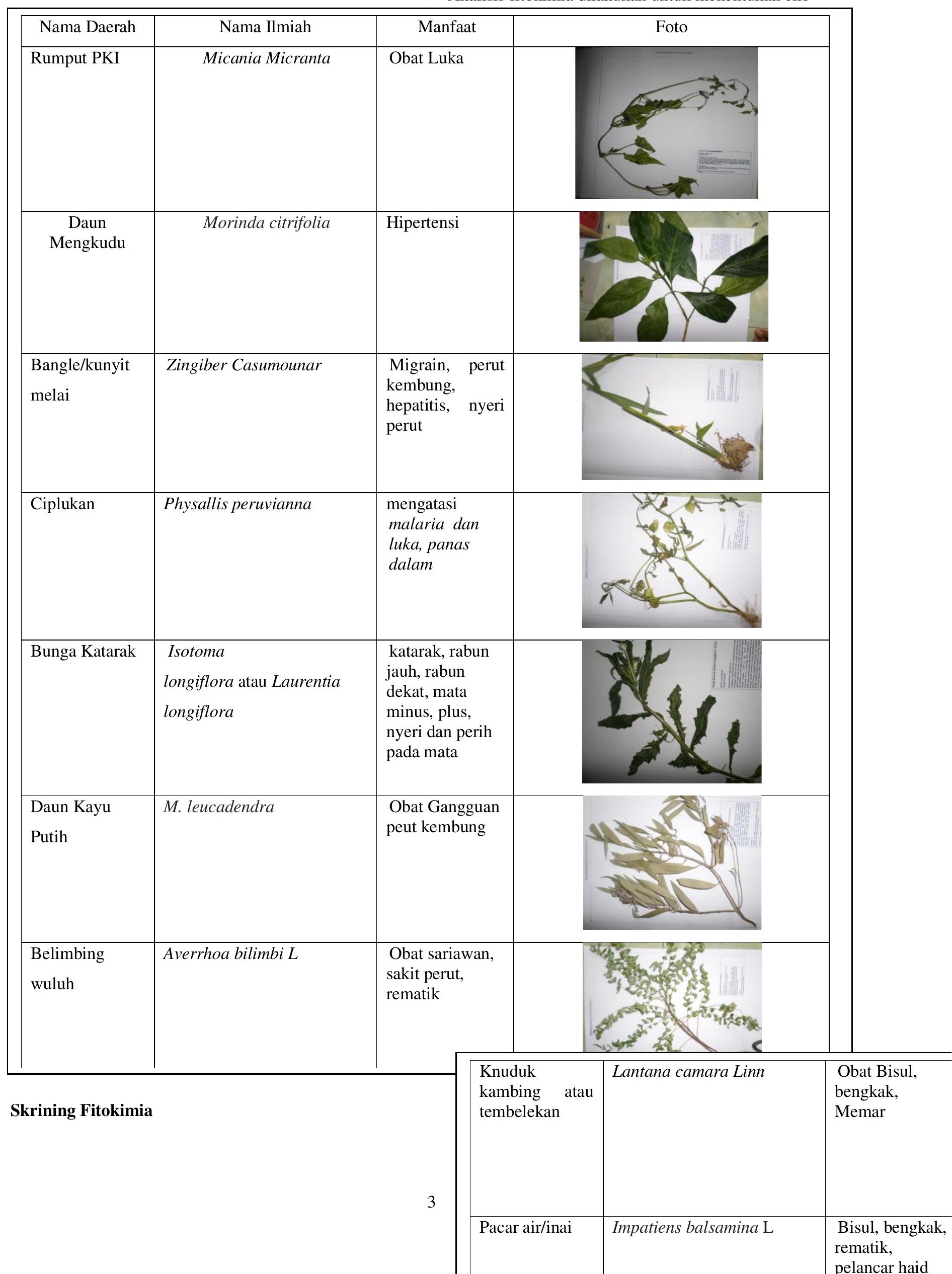


komponen bioaktif suatu ekstrak kasar yang mempunyai efek racun atau efek farmakologis lain yang bermanfaat bila diujikan dengan sistem biologi atau bioassay (Harborne, 1987). Seperti yang ditunjukkan pada tabel 2
Uji Semua sampel menandakan positif mengandung alkaloid. Alkaloid menurut Harborne (1987) merupakan senyawa yang mengandung satu atau lebih atom nitrogen, biasanya dalam bentuk gabungan sebagai bagian dari sistem siklik. Karou, et al. (2006) dalam Hashemi dan Davoodi (2011) menyatakan bahwa alkaloid merupakan 
intercalator DNA dan sebagai penghambat sintesis DNA melalui penghambatan topoisomerase. Selanjutnya Saxena, et al. (2013) menyatakan bahwa alkaloid memiliki aktifitas farmakologi seperti antihipertensi, antikanker, antimalaria dan analgesik. Alkaloid yang terdeteksi positif lemah dalam penelitian ini menunjukan bahwa potensi.

Flavonoid juga menunjukkan komponen tersebut pada seluruh sampel. bahwa flavonoid adalah senyawa polifenolik yang terdapat dalam pangan yang berasal dari tanaman. Flavonoid memiliki pengaruh biologi (in vitro dan in vivo) yang bervariasi terhadap sejumlah sistem sel mamalia. Flavonoid dalam pangan terutama berikatan dengan gula-gula yang disebut glikosida. Kuersetin, sebagai aglikon, berikatan dengan sejumlah gula yang berbeda. Enkhmaa, et al. (2005) berperan dalam mencegah stres oksidatif termasuk atherosclerosis. Polifenol memiliki spektrum luas dengan sifat kelarutan terhadap pelarut yang berbeda-beda (Pambayun, dkk., 2007)

Steroid dalam penelitian ini terdeteksi positif kuat pada semua sampel. Mamahit (2009) mengisolasi satu senyawa steroid dari daun gedi asal Sulawesi Utara yaitu $\beta$-sitosterol, dan hal ini merupakan hal yang pertama kali diisolasi dari daun gedi. Jain, et al. (2009) melaporkan batang Abelmoschus manihot mengandung steroid, dan berdasarkan karakterisasi fisik, kimia dan spektral disimpulkan bahwa senyawa tersebut adalah stigmasterol dan $\gamma$-sitosterol.

Tabel 2. fitokimia tanaman obat

\begin{tabular}{|c|c|c|c|c|c|c|c|}
\hline \multirow{2}{*}{$\begin{array}{l}\text { Bagian } \\
\text { tanaman }\end{array}$} & \multicolumn{2}{|c|}{ Nama } & \multirow{2}{*}{$\begin{array}{l}\text { Uji } \\
\text { Alkaloid }\end{array}$} & \multirow{2}{*}{$\begin{array}{l}\text { Uji } \\
\text { Flavonoid }\end{array}$} & \multirow{2}{*}{$\begin{array}{l}\text { Uji } \\
\text { Steroid }\end{array}$} & \multirow{2}{*}{$\begin{array}{l}\text { Uji } \\
\text { Saponin }\end{array}$} & \multirow{2}{*}{$\begin{array}{c}\text { Uji } \\
\text { Fenolik }\end{array}$} \\
\hline & $\begin{array}{l}\text { Nama } \\
\text { ilmiah }\end{array}$ & $\begin{array}{l}\text { Nama } \\
\text { daerah }\end{array}$ & & & & & \\
\hline $\begin{array}{l}\text { Buah, } \\
\text { daun dan } \\
\text { batang }\end{array}$ & $\begin{array}{l}\text { Physallis } \\
\text { peruvianna }\end{array}$ & $\begin{array}{l}\text { Toup } \\
\text { Ciplukan }\end{array}$ & + & + & + & + & + \\
\hline $\begin{array}{l}\text { Daun } \\
\text { dan } \\
\text { Batang }\end{array}$ & $\begin{array}{l}\text { Micania } \\
\text { Micranta }\end{array}$ & $\begin{array}{l}\text { Rumput } \\
\text { PKI }\end{array}$ & + & + & + & + & + \\
\hline $\begin{array}{l}\text { Daun } \\
\text { dan } \\
\text { Buah }\end{array}$ & $\begin{array}{l}\text { Lantana } \\
\text { camara } \\
\text { Linn }\end{array}$ & $\begin{array}{l}\text { Knuduk } \\
\text { kambing } \\
\text { atau } \\
\text { tembelekan }\end{array}$ & + & + & + & + & + \\
\hline Daun & $\begin{array}{l}\text { Casia Tora } \\
L\end{array}$ & $\begin{array}{l}\text { Ketepeng } \\
\text { atau } \\
\text { gelingging } \\
\text { beras }\end{array}$ & + & + & + & - & + \\
\hline
\end{tabular}

Keterangan: $\quad(+)=$ Terdeteksi

$(-)=$ Tidak Terdeteksi

melaporkan bahwa flavonoid yang merupakan senyawa polifenol dan banyak terdapat dalam buah, sayuran dan tanaman herbal memiliki potensi antioksidan dan mungkin
Hanya pada Casia Tora L atau daun ketepeng Saponin terindikasi, sedangkan sapel lainnya mengandung saponen dengan indikasi positif pada uji sampel. saponin memiliki aktifitas hemolisis terhadap sel darah merah (Khalil dan 
Eladawy, 1994). Saponin berfungsi sebagai antimikroba dan bahan baku untuk sintesis hormon steroid yang digunakan dalam bidang kesehatan karena dapat menghambat dehidrogenasi jalur prostagladin dan steroid anak ginjal (Robinson, 1995). Beberapa studi melaporkan bahwa meskipun saponin tidak beracun dapat menyebabkan respons fisiologi yang berbeda.

Menurut Pelczar dan Chan (2005) Flavonoid, hidrokuinon, dan tanin termasuk golongan senyawa fenol yang bersifat sebagai antibakteri dan senyawa yang bersifat sebagai antimikroba antara lain adalah alkohol, fenolik, klor, iodium, dan etilen oksida. Senyawa fenolik merupakan senyawa yang penting karena merupakan kelas utama di antara senyawa-senyawa penyusun tanaman. Mekanisme antimikroba senyawa fenolik adalah dengan mengganggu kerja di dalam membran sitoplasma mikroba, termasuk di antaranya mengganggu transpor aktif dan kekuatan proton (Harborne, 1987). Menurut Robinson (1995), flavonoid dapat bertindak sebagai antimikroba dan antivirus serta sebagai penampung yang baik bagi radikal hidroksi dan superoksida, sehingga dapat melindungi membran lipid terhadap reaksi yang merusaknya

Dari skrening fitokimia terhadap sampel ekstrak daun ciplukan (Physallis peruvianna) didapat hasil positif alkaloid, flavonoid, steroid, saponin dan fenolik. Menurut (Andrianto.D, N. Anaser, M. Untoro, R.Fatmawati, R.A. Winda, 2012) Ekstrak daun ciplukan menggunakan pelarut etanol $70 \%$ memberikan hasil positif pada semua parameter uji fitokimia meliputi flavonoid, fenolik hidrokuinon, alkaloid, tanin, steroid, dan triterpenoid.

Nama daerahnya rumput PKI atau Micania Micranta menunjukkan positif untuk semua uji. Ini menunjukkan alkaloid, flavonoid, steroid, saponin dan fenolik pada tanaman ini. Menurut (Salam \& Diba, 2014) (Mikania micrantha Kunth) mengandung metabolit sekunder seperti tanin, alkaloid, saponin, steroid dan terpenoid. Komponen ini dapat digunakan sebagai insektisida.

Daun kenuduk kambing menurut atau Lantana camara Linn (Salada, Balala, \& Vasquez, 2015), (Venkatachalam, Kumar, Selvi, Maske, \& Kumar, 2011),
(Kumar \& Maneemegalai, 2008). Secara fitokimia mengandung saponin, tanin dan terpenoid dan pada penelitian ini, fitokimia daun kenuduk kambing didapat hasil positif alkaloid, flavonoid, steroid, saponin dan fenolik. Skrenng fitokimia pada daun, batag dan akar dari kenuduk kambing menunjukkan komponen tanin, catkin, saponin, steroid, fenok, anthroquinone, dan sedikit gula.(Mary, 2011)

Dari uji fitokima daun ketepeng positif mengandung alkaloid, flavonoid, steroid dan fenolik, sedangkan negatif saponin. Menurut (Shaikh \& Syed, 2015) Sampel daun ketepeng atau Casia Tora L mengandung tanin, saponin, protein, steroid, terpenoid, karbohidrat, alkaloid, flavonoid dan glikosida. Bukti ini menunjukkan bahwa daun ketepeng ini dapat dijadikan tanaman obat obatan bahkan berpotensi sebagai bahan baku industri karna mengandung protein dan karbohidrat.

\section{PENUTUP}

\section{Simpulan}

Hasil ekplorasi terdapat 14 Jenis tanaman obat yang sangat sering digunakan oleh masyarakat yaitu Micania Micranta, Morinda citrifoli, Zingiber Casumounar, Physallis peruviann, Isotoma longiflora, M. leucadendra, Averrhoa bilimbi L, Lantana camara Linn, Impatiens balsamina L, Gynura procumbens, Daemonorops didymophyll, Casia Tora L, Jatropha multifida L, dan Oxalis Barrelieri. Dilakukan skrening fitokimia terhadap beberapa tanaman obat tersebut positif mengandung senyawa alkaloid, flavonoid, steroid, saponin dan Fenolik.

\section{Ucapan Terima Kasih}

Terima Kasih Kepada Dikti, Kopertiis wilayah X yang telah mendukung pelaksanaan penelitian ini melalui pendanaan penelitian Pemula dan Universitas muara Bungo atas sarana dan prasarana penelitian

\section{DAFTAR PUSTAKA}

Andrianto.D, N. Anaser, M. Untoro, R.Fatmawati, R.A. Winda, S. A. (2012). pengaruh ekstrak daun ciplukan ( physallis peruviana $l$.) terhadap kelarutan batu ginjal in vitro effect of physallis peruviana $l$. leaves extract on the solubility of kidney stone in vitro. Prosiding Seminar Nasional Kimia Unesa 2012 - ISBN : 978-979-028-550-7, 978-979. 
Achmad, S.A., 2006, Kimia Bahan Alam dan Potensi Keanekaragaman Hayati, Workshop Peningkatan Sumber Daya Manusia Pengelolaan dan Penelitian Potensi Keanekaragaman Hayati, Padang.

Astuti SM, Mimi SAM, Retno ABM. \& Awalludin R. 2011.a. Determination of Saponin Compound from Anredera cordifolia (Ten) Steenis (Binahong) to potential treatment for several deseases. Journal of Agricultural Science, Canadian Center of Science and Education. Vol 3.No 4, December, 2011 pp 224 -232 .

Amzu, e. Dan haryanto. 1990. Pelestarian pemanfaatan tumbuhan obat di Indonesia. Seminar Nasional Pelestarian Pemanfaatan Tumbuhan Obat, Bogor.

Cifor ., 2008. Belajar Dari Bungo mengelola sumberdaya alam di era desentralisasi.

Departemen Kesehatan RI, 1989, Materia Medika Indonesia, Jilid VI, Jakarta

Edeoga HO, Okwu DE. \& Mbaebre BO. 2005. Phytochemical Constituent of Some Nigerian Medicinal Plants. Afr Journal of Biotechnology 4: 685-688.

Enkhmaa, B., Shiwaku, K., Katsube, T., Kitajima, K., Anuurad E., Yamasaki M. and Yamane Y. (2005) Mulberry (Morus alba L.) leaves and their major flavonol quercetin 3-(6-mal- onylglucoside) attenuate atherosclerotic lesion development in $L D L$ receptor-deficient mice. J. Nutr., 135, 729-734

El-Adawy, T.A. and Khalil, A.H. (1994) Characteristics of Roselle Seeds as a New Source of Protein and Lipid. Journal of Agricultural and Food Chemistry, 42, 1986-1900

Febrialdi, A. (2017). Identifikasi dan Inventarisasi Tanaman obat yang digunakan Masyarakat di Hutan Kecamatan Bathin III Ulu Kabupaten Bungo. Jurnal Sains Agro, 1(1).

Febrialdi, A. (2017). Kondisi Beberapa Plasma Nutfah Non Kayu Disekitar Hutan Kecamatan Rantau Pandan Muara Bungo. Jurnal Sains Agro, 1(1).

Figen MT. 2006. Saponin versus Plant Fungal Pathogens. Journal of Cell and MolecularBiology 5: 13-17

Harborne, J. B. 1987. Metode Fitokimia : Penuntun Cara Modern Menganalisis Tumbuhan. Institut Teknologi Bandung, Bandung. (diterjemahkan oleh Kosasih Padmawinata dan Iwang Soediro).

Harborne JB. 1973. Phytochemical Method, London, Chapman and Hall, Ltd. pp 49-188.
Harbone, J.B., 1987, Metode Fitokimia: Penuntun Cara Modern Menganalisis Tumbuhan, Terbitan Kedua, ITB Bandung

Idha Kusumawati, Wahjo Djatmiko, Abdul Rahman, Herra Studiawan, Wiwied Ekasari., 2003. Eksplorasi Keanekaragaman Dan Kandungan Kimia Tumbuhan Obat Di Hutan Tropis Gunung Arjuno., Jurnal Bahan Alam Indonesia Issn 1412-2855 vol. 2, no. 3

Jain C, et al. (2009) A Pathogenesis assay using Saccharomyces cerevisiae and Caenorhabditis elegans reveals novel roles for yeast AP-1, Yapl, and host dual oxidase BLI-3 in fungal pathogenesis. Eukaryot Cell8(8):1218-27

Kumar, M. S., \& Maneemegalai, S. (2008). Evaluation of Larvicidal Effect of Lantana Camara Linn Against Mosquito Species Aedes aegypti and Culex quinquefasciatus. Advances in Biological Research, $2,39-43$.

Karou D, Savadogo A, Canini A, Yameogo S, Montesano C, Simpore J, Traore A. Antibacterial activity of alkaloids from Sida acuta. African Journal of Biotechnology. 2006;5(2):195-200.

Kemala, Sudiarto S, Pribadi ER, Yuhono JT, Yusron M, Mauludi L, Raharjo, Waskito B, dan Nurhayati H. 2003. Studi Serapan, Pasokan dan Pemanfaatan Tanaman Obat di Indonesia. Laporan teknis penelitian Bagian Proyek Penelitian Tanaman Rempah dan Obat APBN

Mary, K. (2011). Studies On Phytochemical Screening And AntibacteriaL. Plant Sciences Feed, 1(5), 7479.

Masniari Peoloengan1, Chairul2, Iyep Komala3, Siti Salmah2, Susan M.N.1 2006., Aktivitas Antimikroba Dan Fitokimia Dari Beberapa Tanaman Obat., Seminar Nasional Teknologi Peternakan Dan Veteriner.

Mi-Jeong A. \& Jim WK. 2005. Identification and Qualification of Steroidal Saponins in Polygonatum Species by HPLC/ESI/MS. Arch. Pharm. Res. Vol 28 No5.592-597

Marinova DF, Ribonova. \& Allanasova M. 2005. Total Phenolic and Total Flavonoid in Bulgarian Fruits and Vegetables. Journal of The University of Chemical Technology and Metallurgy 40, 3: 255260.

Manoi F. 2009. Binahong (Anredera cordifolia) Sebagai Obat. Bulletin Warta Volume 15, Number 1, April 2009. Penelitian dan Pengembangan Tanaman Industri. Badan Penelitian dan Pengembangan 
Pertanian. Pusat Penelitian dan Pengembangan Perkebunan, Indonesia. Hal. 4-5.

Pambayun, R., Gardjito, M., Sudarmadji, S. dan Kuswanto,K.R. (2007). Kandungan Fenol dan Sifat Antibakteri dari Berbagai Jenis Ekstrak Produk Gambir (Uncaria gambir Roxb). Majalah Farmasi Indonesia 18 (3): 141-146

Pelczar,M.J; and E.C.S.Chan. 2005. Dasar-Dasar Mikrobiologi. Jilid 2. Jakarta: UI-pres

Robinson et al., (1995) Elements of Cartography, 6th. Edition. New York: John Wiley \& Sons

Salada, J. T., Balala, L. M., \& Vasquez, E. A. (2015). Phytochemical and Antibacterial Studies of Lantana camara L. Leaf Fraction and Essential Oil. International Journal of Scientific and Research Publications, 5(3), 1-5.

Salam, D. M., \& Diba, F. (2014). Pengendalian Rayap Tanah Coptotermes curvignathus Holmgren Menggunakan Ekstrak Daun Gulma Sembung Rambat ( Mikania micrantha Kunth ). Jurnal Protobiont, 3(2), 87-92.

Shaikh, R., \& Syed, I. Z. (2015). Proximate and Phytochemical Analysis of Cassia Tora Leaves. Journal of Research in Pharmaceutical Science, 2(8), 1-3.

Suriyani. 2010. Mengenal Simplisia Tumbuhan Obat[terhubung berkala] http://healthcarepharmacist.blogspot.com/2011/06/pembuatansimplisia-dan-ekstrak

Santos, Alfredo C, Beatrice QG, Alicia MM. \& Estrada CQ. 1989. Phytochemical, Microbiological and Pharmacological Screening of Medicinal Plants, GHS Publishing Cooperation, Manila. pp. 15171525 .

Sri Murni., 2013. Astuti. Skrining Fitokimia Dan Uji Aktifitas Antibiotika Ekstrak Etanol Daun, Batang, Bunga Dan Umbi Tanaman Binahong (Anredera Cordifolia (Ten) Steenis). Balai Besar Pengujian Mutu dan Sertifikasi Obat Hewan (BBPMSOH) dan Fakulti Kejuteraan Kimia dan Sumber Asli (Bioproses), Universiti Malaysia Pahang, Kuantan Pahang, Malaysia

Saxena, A., Peng, B.N., and Bronner, M.E. (2013) Sox10dependent neural crest origin of olfactory microvillous neurons in zebrafish. Elife 2: e00336.

S.R. Hashemi and H. Davoodi, 2012. Herbal Plants as New Immuno-stimulator in Poultry Industry: A Review. Asian Journal of Animal and Veterinary Advances, 7: 105-116.

Sudirman, S., Nurhjanah., Abdullah, A. 2011. Aktivitas antioksidan dankomponen bioaktif kangkung air.
Utami Sri, A. (2012). Potensi Pemanfaatan Tumbuhan Obat Di Kabupaten Lampung Barat Dan Kabupaten Tanggamus, Provinsi Lampung. Balai Penelitian Kehutanan Palembang (Vol. XXXIII).

Venkatachalam, T., Kumar, V. K., Selvi, P. K., Maske, A. O., \& Kumar, N. S. (2011). Physicochemical And Preliminary Phytochemical Studies On The Lantana Camara ( $L$.) FRUITS. International Journal of Pharmacy and Pharmaceutical Sciences, 3(1), 3-5. 